\title{
THE INFLUENCE OF MIND MAPPING IN TEACHING READING COMPREHENSION TO THE EIGHTH GRADE STUDENTS OF SMP MUHAMMADIYAH 1 RAWA BENING
}

\author{
Dwi Andriani \\ English Education Study Program of STKIP Nurul Huda Sukaraja \\ Email: dwiandriani@stkipnurulhuda.ac.id
}

\begin{abstract}
The objectives of this study is: "to find out whether or not there Is the influence between the students who are taught by using mind mapping technique and who are not taught by using mind mapping technique ". The 60 samples out of 120 students from the eighth grade students were chosen by means purposive sampling technique. It used quasi-experimental method, nonrandomized pretest and posttest design. The data was analyzed using independent t-test for SPSS. The result showed that t-obtained was 6.20 , while t-table was 2.04 . it means that there was the influence between the students who were taught by using mind mapping technique and who were not taught by using mind mapping technique.
\end{abstract}

Keywords: Teaching, Reading Comprehension, Mind Mapping Technique

\section{INTRODUCTION}

English is considered essential as a means of communication which is used as a global language. English is used as a second language for most people in the world. According to UNESCO (2009), English leads world languages as far as communication and publication is concerned. Freeman and Long (1991) observe that English has become the international language for business and commerce, science and technology, international relations and diplomacy. Therefore, it is important that English is learnt so that people can fit well in the international community.

In Indonesia, English is learnt as a foreign language which is taught as a compulsory subject from elmentary to universities. Students learn English as a means to broaden their knowledge about science, technology, culture, and arts. The students are expected to be able to master English orally and in writing (Department of National Education, 2006). It is stated that the aims of teaching English in Indonesia are to utilize the language to broaden the students' reasoning horison as well as to improve their communicative competence.

In teaching English at junior high school in Indonesia, the teachers teach the language based on Curriculum 2008 which is known as School-Based Curriculum. The curriculum states that the aim of teaching English at junior high school is to develop four components of language skills: listening, speaking, reading and writing. Schools have the authority and autonomy to make operational policies most appropriate for their own contexts. Thus, in implementing the competency-based curriculum, schools may decide on what competencies to include in addition to the set of competencies from the Ministry of National Education and to choose the learning materials deemed appropriate to develop those competencies. By the same token, schools can also develop their own teaching-learning materials, methods, media, and assessment. Therefore, there will be the national curriculum and the school curriculum.

Skills in reading (and learning information from) texts written in English as a foreign language (EFL reading) constitute an important element of the establishment of English curriculum of secondary and tertiary schools (both English and non-English departments) in Indonesia. The need of the learners to be skillful in reading to learn has inspired EFL reading teachers or specialists to apply some techniques in the teaching of EFL reading and to investigate the effects of the techniques on improving Indonesian students reading skills, as well as to examine various related aspects such as reading 
materials, reading strategies, and factors affecting reading comprehension (Cahyono \& Widiati, 2006, p. 36).

The teaching of reading as a foreign language in Indonesia can be generally included in the teaching of reading comprehension. This is because it aims to improve the skills of learners, who have been able to read in their first language and in EFL, in understanding the meaning of a written text. It is essential then that EFL reading instructors and researchers in the Indonesian context understand the reading process and the relationship between this process and the acquisition of messages, knowledge, or information from reading texts or other written materials (Cahyono \& Widiati, 2006, p. 37-38). Comprehension is the ultimate goal of reading. Therefore, the primary purpose of reading instruction is to develop the skills and strategies for the students to construct meaning from text. Students must read a lot. In addition, students must develop their knowledge base on a variety of topics in order to understand a wide array of texts. Overall, comprehension instruction must teach students how to intentionally interact with the text to create meaning (Chard \& Santoro, 2008, p. 9).

According to Nugroho $(2009$, p.2), in reading over 50 percent of students surveyed in Indonesia performed at level 1 - the lowest out of five - or below. Level 1 represents those students who have serious difficulties in using reading as a tool to advance and extend their knowledge and skills in other areas. Level 5 indicates those students who are able to manage information that is presented in unfamiliar texts, show detailed understanding of complex texts and infer which information is relevant to the task, and critically evaluate and build hypotheses with the capacity to draw on specialized knowledge and concepts that may be contrary to expectations. It was also found that the lowest results of that were scored in Albania, Indonesia and Peru.

According to Progress in International Reading Literacy Study (PIRLS) in 2011 is the International study about reading children in the World, Indonesia is on the 41 st of 45 countries in the world. In addition, PISA 2009 database shows that Indonesia students' score is below the OECD average and on the 57th of 65 countries (OECD, PISA 2009 Database). Based on the sources of SMP Muhammadiyah 1 Rawa Bening, it was found out that the students' average score for the students' tests in 2009-2011 for the seventh and eight grade students was below standard (5.00) while the standard was 7.00, while for the teacher, the writer also finds that the teachers seldom varied their strategies in teaching learning process of English in the classroom. Therefore, the writer thinks that English teaching and learning at SMP Muhammadiyah 1 Rawa Bening should be modified and varied in terms of teaching strategies.

The ability of Indonesian students to read English texts was very low (Hamra \& Syatriana, 2012). Most university graduates are not able to read English with complete comprehension. The Indonesian students need help in reading comprehension. For students, reading is a key to improve learning outcome in many fields of study. There are many universities and teacher training institutions have developed courses to deal with the teaching of reading comprehension. Yet, when it comes down to it, the classroom teacher is left with the enormous task of adapting all these materials and ideas to his/her particular class. This supplement is also intended to help the teacher in the daily decision-making process within the reading comprehension lesson and across national standard.

Hart \& Risley (2003, p. 4) inform that teaching students specific learning strategies increases understanding of content while they promote critical thinking skills. It means, the method which is used by the teacher may influence the result of teaching and learning activities. Pearson, Rochler, Dole \& Duffy (1992, p. 1) on developing expertise in reading comprehension state:

A good reader usually uses prior knowledge to make sense of new information; asks question about the text before, during, and after reading; draws inferences from text; monitors comprehension; uses fix up strategies when meaning breaks down; determines what is important; and synthesizes information to create sensory image.

To encourage students to develop effective reading skills, there are various teaching and learning strategies that can be used by the teachers in classroom. In order to fully understand the present 
technique of teaching reading, one must know something of former practices. Selecting appropriate materials to students' need is very important, because it is impossible that materials will be good and interesting if the methodology way is boring and does not motivate the students to study them eagerly. Brown (1994:48) says, "Techniques are the specific activities manifested in the classroom that are consistent with a method and therefore in harmony with an approach as well."

Memory sensory has important value in learning reading comprehension. The students need balancing in usage of the left brain (cognitive) and right brain (audio visual (affective and psychomotor)) (Windura, 2002:5). If we cannot use the balancing in usage of brain, it will have the effect or problem in study, they are: cannot concentrate, cannot understand what they learn, easy to forget material, and the brain feel full so cannot study again (Windura, 2002:7). The students need balancing in usage of the left brain and right brain. Whole brain is needed by the students to think perfectly. Right brain is for creativity and visualization. Left brain is for logical and rational. Mind mapping combines both and become whole-brained. It stimulates the brain by appealing to both the creative and logical side of the brain. Mind map use all brain management principles, focus on using left and right brain actively and synergic (Windura, 2002: 10). According to DePotter and Hernacki, 2008:152), Mind mapping uses visuals reminder and sensory into a pattern from the ideas which are related. It starts with the students' main topic or the theme as the central idea and allows the main branches of mind mapping to represent the main points of their thought (right brain) then combined by the interesting colors' and images (left brain) which will stimulate the brain. The writer chooses mind mapping as a technique to help the students in comprehend reading and memorizing the words which are expected in improving their reading comprehension proficiency by memorizing easily.

Mind mapping is believed as one of the techniques or activities which is used on teaching reading comprehension which involve the essential idea and encourages memorizing easily.

\section{LITERATURE REVIEW}

Devine (1987: 7) argues that reading comprehension is a process of activating the prior knowledge of the reader which cooperates with his appropriate cognitive skills and reasoning ability to find out the concept from a printed text. In these words, the reader must be able to understand, to interpret and to select actual information from text. It means that the knowledge that was possessed by the readers influence the ability of the readers in comprehending what they read. The readers have to be able to use their prior knowledge in order to help them to comprehend the texts that they read. It guides them to have better understanding about something, so that reading activity can improve their knowledge because reading can give many advantages.

The more people read, the more they get. Thorndike (1992: 18) states that reading in a second language, however, may not so easily fit into this pattern because the neccessary background information and familiarity with the language may be missing. That is, the reader might not have an appropriate schema available.

Buzan (1993:1) states that mind mapping is a powerful graphic technique, which provides a universal key to unlock the potential of brain. Mind mapping technique imitates the thinking process, namely possible us to move from one topic to another topics back and forth. Recording the information through symbols, pictures, emotional meaning and colors, exactly the same like our brains process it. A pattern which at least consists of picture, symbol and color that will not just help the students to understand the vocabulary knowledge but also makes the students feel good, enjoyable and attract their brain which at last lead them to have interest in mastery vocabulary knowledge.

Windura (2002: 7) states that mind mapping is the easiest way to help whoever save the time shortly until a half to finish their assignment. It also helps students make a note of lesson more interesting, easy to be remembered and understood.

There are some parts of mind mapping (Windura, 2008:77-86) namely; (1) central image, (2) key word, (3) basic ordering ideas, (4) branches, (4) colour and (5) picture. 
Dwi Andriani

\section{Central Image}

A central image has to describe the main idea of a mind mapping and put it on the centre of the paper. It is for activate the students' right brain, strengthen the students' memory and make the learning activity enjoyable.

\section{Key Word}

A key word is a word that can lead a sentence or event. Identifying a familiar word in one's own language or another language that sounds like the new word and using only one key word per line. It is as an urge to remember a lot of words for the students. It is strong noun or verb that creates image to trigger recall the memory.

\section{Basic Ordering Ideas}

Basic ordering ideas are the branches that collect sort information and it connected to the central topic that radiate out from the centre. Making basic ordering ideas which can direct our mind to make mind mapping and it need creativity that encourage the students to understand to the material. It is thick and thinner at the ends. It can be seen as headings for your topic and spread anywhere but do not become steep.

\section{Branches}

The branches should be curvy and in the same length as the words or pictures above it. These branches can be seen as sub headings. It is thinner branches and containing details.

\section{Colour}

Colour is a very good memory sign and it involves the right brain in learning for long term memory. Colours encourage creativity and help in memorization. Adding plenty of colours via branches, map background and images will add life to your mind map. It makes easier to comprehend and remember.

Picture

In mind mapping, pictures which can change or strengthen a key word that has been written before.

\section{Method of the Study}

\section{METHODOLOGY}

This research used experimental research. That is, quasi-experimental research, nonrandomized pretest dan posttest design. In this design, the writer had two groups of sample: the first is experiment class by using mind mapping technique, the second is control class.

\section{a. Population}

For the population of this study, the writer will choose the eighth grade students of SMP Muhammadiyah 1 Rawa Bening. In this case, there are four classes. The total number of population is 120 students. The information of total number of the eighth grade students of SMP Muhammadiyah 1 Rawa Bening is shown in Table.

Table 1: The Population Of The Study

\begin{tabular}{ccc}
\hline No. & Class & Number of Student \\
\hline 1. & VIII.A & 30 \\
2. & VIII.B & 30 \\
3. & VIII.C & 30 \\
4. & VIII.D & 30 \\
\hline & Total & 120 \\
\hline
\end{tabular}

\section{b. Sample}

For this research, purposive sampling technique was used. Fraenkel and Wallen (1991:138) state that in purposive sampling the researchers use their judgement to select the sample for a specific 
purpose.

In this research, the researcher selected the students based on the criteria:(1) The students were taught by the same teacher, (2) The students were in the same grade level (class), (3) They never took English course, (4) they got the same problem in reading comprehension.. And then the researcher took the sample for each experimental (VIII.A) and control group (VIII.D), they were shown below:

Table 2: Sample

\begin{tabular}{lcc}
\hline No & Class & Number of Student \\
\hline 1. & $\begin{array}{c}\text { Experimental class } \\
\text { (VIII A) }\end{array}$ & 30 \\
2. & $\begin{array}{c}\text { Control class } \\
\text { (VIII C) }\end{array}$ & 30 \\
\hline & Total & 60 \\
\hline
\end{tabular}

\section{FINDINGS}

It was found out that there was a significant difference in reading comprehension achievement of the students between before and after they were taught using mind mapping technique. In the pre-test, the students were given the test. The tests in the pre-test and the post-test were the same, but before the posttest was given, the students were taught using mind mapping technique. The result showed a progress in the posttest than in the pre test. It might be caused by the treatment given to them.

From statistical analysis from posttest of experimental and control class, it was found out that the mean score of posttest for experimental class was 78.53, meanwhile control class was 65.73 . it means that experimental class was better than control class. Moreover from the result of t-obtained in finding was higher than t-table. It means that there was the influence between students who were taught by using mind mapping technique and those who were not taught by using mind mapping technique. It could be interpreted that teaching reading comprehension by using mind mapping is better than it was done teacher over there.

\section{CONCLUSIONS AND SUGGESTIONS}

From the findings and interpretations in the previous chapter, the conclusion could be drawn that there the influence between the student's reading comprehension achievement in mind mapping technique and conventional. After the treatment, it was found that using mind mapping technique was more effective than conventional technique.

The suggestion for the teacher, this strategy is good to be implemented in the process of teaching and learning. More often in order to develop students' reading, the teacher should never stop trying suitable technique/strategy in order to make the teaching learning process in the classroom more effective. It is hoped to other interested researcher to conduct a similar research with more sample, more time spent in treatment in order to strengthen the finding of this study. Finally, for the students, they must have internal motivation to read more or study reading to enhance their knowledge, good preparation achieve and ideal objective in the process of teaching and learning especially in reading comprehension.

\section{REFERENCES}

Brown, H.D. (1994). Teaching by Principles: An Interactive Approach to Language Paedagogy. San Francisco: Prentice-Hall, Inc.

Buzan, T. (2007). Buku pintar mind map. Jakarta: PT. Gramedia Pustaka Utama.

Cahyono, B.Y., \& Widiati, U. (2006). The teaching of EFL reading in the Indonesian context: the state of the art. TEFLIN Journal. 17(1), 53-55.

Chard, D., \& Santoro, L.E. (2008). Building a community of reading experts: What is reading 
comprehension and why is it important?. Eugene: University of Oregon,.

Badan Standar Nasional Pendidikan. (2006). Standar isi. Jakarta: Departemen Pendidikan Nasional.

Devine, T. G. (1987). Teaching reading comprehension from teaching to practice. Boston: Merril Publishing.

Freeman, D. L., \& Long, M. H. (1991). An introduction to second language acquisition research. Cambridge : Longman Group.

Hart, B., \& Risley, T. R. (2003). The early catastrophe: The 30 million word gap by age 3. American Educator, 1(2), 4-9.

Direktorat Tenaga Kependidikan. (2008). Kurikulum tingkat satuan pendidikan (KTSP). Direktorat Jenderal Peningkatan Mutu Pendidik dan Tenaga Kependidikan: Departemen Pendidikan Nasional.

Nugroho, T. (2009). Teaching reading. Jakarta: Ministry of National Education.

OECD. What students know and can do: Student performance in reading, Mathematics and Science (Vol. I). Available at http://dx.doi.org/10.1787/9789264091450-en. (Accessed 16 February 2010).

Pearson, P. D., Roehler, L., Dole, J., \& Duffy, G. (1992). Developing expertise in reading comprehension. In S.J. Samuels \& A.E. Farstrup (Eds.), What research has to say about reading instruction (pp. 145-199). (2nd ed). Newark, DE: International Reading Association.

Thorndike, R. D. 1992. Reading in a foreign language: Identification of subskills of reading comprehension by maximum likelyhood factor analysis. Chicago: Riverside Publishing.

UNESCO. Mother tongue multilingual education. Available at http://www.portal.unesco.org/education/en/ev/. (Accessed 2 June 2009).

Windura, S. (2008). Mind map : Langkah demi langkah. Jakarta: PT. Elex Media Komputindo. 